\title{
Cytotoxic activity of Parmelia perlata extracts against Artemia salina
}

\section{Mayilsamy ${ }^{1 *}$, K. Geetharamanan ${ }^{2}$}

'Department of Botany, Arulmigu Palaniandavar College of Arts and Culture, Palani, Dinidigul, Tamil Nadu, India, ${ }^{2}$ Sri ALV High School, Theni, Tamil Nadu, India

Received: 24.03 .2016
Accepted: 11.06 .2016
Published: 22.06 .2016
*Address for
correspondence:
M. Mayilsamy, Department
of Botany, Arulmigu
Palaniandavar College of
Arts and Culture, Palani,
Dinidigul - 624 001,
Tamil Nadu, India. E-mail:
mmkannivadi@gmail.com

Received: 24.03.2016

Accepted: 11.06.2016

*Address for

of Botany, Arulmigu

Palaniandavar College of

Dinidigul - 624001

mmkannivadi@gmail.com

\begin{abstract}
The brine shrimp lethality bioassay represents a rapid, inexpensive, and simple bioassay for testing plant extracts bioactivity which in most cases correlates reasonably well with cytotoxic and antitumor properties. The assay is considered to be a very useful tool for preliminary assessment of toxicity. In this study, the lichen Parmelia perlata was extracted with solvents of varying polarity such as hexane, ethyl acetate, acetone, and methanol and tested for hatch inhibition of cysts of Artemia salina and cytotoxic activities against $A$. salina naupilii. The highest cytotoxic potential among all the plant extracts tested was explored from the hexane extract of $P$. perlata which showed $100 \%$ brine shrimp mortality at $100 \mathrm{ppm}$. The least activity among all the plant extracts was found in the methanol extract of $P$. perlata.
\end{abstract}

KEY WORDS: Parmelia perlata, crude extract, Artemia salina, cytotoxic activities

\section{INTRODUCTION}

Natural therapies, such as the use of plant-derived products in cancer treatment, may reduce adverse side effects. Currently, a few plant products are being used to treat cancer. However, a myriad of many plant products exists that have shown very promising anti-cancer properties in vitro but have yet to be evaluated in humans (Desai et al., 2008).

The plants have been used for medicinal purposes throughout human history, and the first pharmaceuticals were derived from medicinal plants (McRae et al., 2007). Globally, there is a positive trend in favor of traditional medicine and ethnopharmacology. The brine shrimp lethality bioassay represents a rapid, inexpensive, and simple bioassay for testing plant extracts bioactivity which in most cases correlates reasonably well with cytotoxic and antitumor properties. The assay is considered to be a very useful tool for preliminary assessment of toxicity and it has been used for the detection of fungal toxins, toxicity of plant extracts, heavy metals, and cytotoxicity testing of dental materials (Sharma et al., 2013).

Various active compounds derived from medicinal plants have been assessed for their efficacy and tolerability in the treatment of breast cancer. Some of these plant species including Taxus baccata (paclitaxel, docetaxel), Podophyllum peltatum (etoposide), Camptotheca acuminata (camptothecin), and Vinca rosea (vinblastine, vinorelbine) have well recognized antitumor activity in breast cancer and have been evaluated in clinical trials. The plants are good and cheap sources for the prevention and treatment of oxidative stress and cancer (Richard et al., 2015). The treatment of cancer by use of natural products and traditional medicine by applying the concepts of Ayurveda is attaining a great significance scope of cancer research. Medicinal plants contain good immunomodulatry and antioxidant properties which lead them to be an anticancer drug (Priya et al., 2015).

The lichen Parmelia perlata is used as one of the important spices in India. It is liked for its flavor. The P. perlata is as anti-emetic substance, i.e. used to stop vomiting (Rao et al., 2011) and also used in traditional medicine for rapid wound healing (Vidyalakshmi and Kruthika, 2012). In this study, the lichen P. perlata was extracted with solvents of varying polarity such as hexane, ethyl acetate, acetone, and methanol and tested for hatch inhibition of cysts of Artemia salina and cytotoxic activities against A. salina naupilii. 


\section{MATERIALS AND METHODS}

\section{Preparation of Extracts}

The lichen P. perlata (Huds.) Ach. was purchased commercially and then ground by using an electric blender. The powdered material was extracted by soaking $25 \mathrm{~g}$ powder at room temperature in Erlenmeyer flasks containing $250 \mathrm{ml}$ of solvents such as hexane, ethyl acetate, acetone, and methanol for $72 \mathrm{~h}$. The extraction process was carried out in triplicates. After $72 \mathrm{~h}$, the extract was filtered through Whatman No. 1 filter paper and the solvent was evaporated under vacuum in a rotary evaporator and the dried extracts were stored at $4{ }^{\circ} \mathrm{C}$ until further assay.

\section{Brine Shrimp Lethality Bioassay}

Brine shrimp lethality bioassay is considered a useful tool for preliminary assessment of toxicity. The method is attractive, because it is very simple, inexpensive and sensitive (Krishnaraj et al., 2005). 10 nauplii were drawn through a glass capillary and placed in test tubes containing $10 \mathrm{ml}$ of artificial seawater solution and $0.5 \mathrm{ml}$ of the diluted plant extract $(5.0,10,25$, $50,100 \mathrm{ppm}$ ) was added to it and maintained at room temperature for $24 \mathrm{~h}$ under constant aeration and light source. The test was also carried out on control (artificial sea water). The Artemia mortality in both treated and control was recorded after $24 \mathrm{~h}$ and the percentage of mortality calculated.

$$
\% \text { Mortality }=\frac{- \text { mortality at control }}{100-\text { mortality at control }} \times 100
$$

\section{Statistical Analysis}

The lethal concentrations, $\mathrm{LC}_{50}$ and $\mathrm{LC}_{90}$ at which concentrations (ppm) 50\% and 90\% larvae showed mortality, 95\% confidence limit of upper and lower confidence levels were calculated by Probit analysis (SPSS, version 11.5).

\section{RESULTS AND DISCUSSION}

The brine shrimp mortality of P. perlata is given in Tables 1-4. The highest brine shrimp mortality of $100 \%$ was recorded with hexane and methanol extracts at 100 and $200 \mathrm{ppm}$, respectively. The ethyl acetate extract at 200 ppm showed $92.6 \%$ brine shrimp mortality, whereas acetone showed $82.0 \%$ mortality and $213.29 \mathrm{ppm}$.

In our study, a dose-dependent result was recorded. The hatch inhibition of $A$. salina cysts was increased with increasing concentration of plant extracts. A similar observation was made by Sabai et al. (2001) and Otang et al. (2013).

The highest cytotoxic potential among all the plant extracts tested was explored from the hexane extract of P. perlata which showed $100 \%$ brine shrimp mortality at $100 \mathrm{ppm}$.

\begin{tabular}{|c|c|c|c|c|c|c|}
\hline \multirow[t]{2}{*}{ Concentration (ppm) } & \multirow[t]{2}{*}{ Brine shrimp mortality (\%) } & \multirow[t]{2}{*}{$\mathrm{LC}_{50}(\mathrm{ppm})$} & \multirow[t]{2}{*}{$\mathrm{LC}_{90}(\mathrm{ppm})$} & \multicolumn{2}{|c|}{ 95\% fiducial limit (ppm) } & \multirow[t]{2}{*}{ Chi-square } \\
\hline & & & & $\mathrm{LCL}$ & UCL & \\
\hline 12.5 & 22.40 & 26.28 & 66.63 & $16.53-38.62$ & $43.94-191.37$ & $12.379 *$ \\
\hline 25 & 36.80 & & & & & \\
\hline 50 & 78.60 & & & & & \\
\hline 100 & 100.00 & & & & & \\
\hline 200 & 100.00 & & & & & \\
\hline Control & 1.0 & & & & & \\
\hline
\end{tabular}

Table 1: LC of hexane extract of $P$. perlata against brine shrimp (A. salina)

*Significant at $P<0.05$. P. perlata: Parmelia perlata, A. salina: Artemia salina, LCL: Lower confidence limit, UCL: Upper confidence limit, LC: Lethal concentration

\begin{tabular}{|c|c|c|c|c|c|c|}
\hline \multirow[t]{2}{*}{ Concentration (ppm) } & \multirow[t]{2}{*}{ Brine shrimp mortality (\%) } & \multirow[t]{2}{*}{$\mathrm{LC}_{50}(\mathrm{ppm})$} & \multirow[t]{2}{*}{$\mathrm{LC}_{90}(\mathrm{ppm})$} & \multicolumn{2}{|c|}{ 95\% fiducial limit (ppm) } & \multirow[t]{2}{*}{ Chi-square } \\
\hline & & & & LCL & UCL & \\
\hline 12.5 & 16.5 & 45.02 & 211.10 & $38.67-52.27$ & $163.60-296.76$ & 3.056 \\
\hline 25 & 32.4 & & & & & \\
\hline 50 & 48.0 & & & & & \\
\hline 100 & 72.5 & & & & & \\
\hline 200 & 92.6 & & & & & \\
\hline Control & 0.0 & & & & & \\
\hline
\end{tabular}

Table 2: LC of ethyl acetate extract of $P$. perlata against brine shrimp ( $A$. salina)

P. perlata: Parmelia perlata, A. salina: Artemia salina, LCL: Lower confidence limit, UCL: Upper confidence limit, LC: Lethal concentration 
Table 3: LC of acetone extract of $P$. perlata against brine shrimp (A. salina)

\begin{tabular}{lccccc}
\hline Concentration $(\mathrm{ppm})$ & Brine shrimp mortality (\%) & $\mathrm{LC}_{50}(\mathrm{ppm})$ & $\mathrm{LC}_{90}(\mathrm{ppm})$ & \multicolumn{2}{c}{$95 \%$ fiducial limit (ppm) } \\
\cline { 4 - 5 } & & & & $\mathrm{LCL}$ & $\mathrm{UCL}$ \\
\hline 12.5 & 13.6 & 62.80 & 384.19 & $53.01-75.25$ & $271.97-624.14$ \\
25.0 & 25.9 & & & & \\
50.0 & 42.8 & & & & \\
100.0 & 59.6 & & & & \\
200.0 & 82.0 & & & & \\
Control & 0.0 & & & & \\
\hline
\end{tabular}

P. perlata: Parmelia perlata, A. salina: Artemia salina, LCL: Lower confidence limit, UCL: Upper confidence limit, LC: Lethal concentration

Table 4: LC of methanol extract of Parmelia perlata against brine shrimp ( $A$. salina)

\begin{tabular}{|c|c|c|c|c|c|c|}
\hline \multirow[t]{2}{*}{ Concentration (ppm) } & \multirow[t]{2}{*}{ Brine shrimp mortality (\%) } & \multirow[t]{2}{*}{$\mathrm{LC}_{50}(\mathrm{ppm})$} & \multirow[t]{2}{*}{$\mathrm{LC}_{90}(\mathrm{ppm})$} & \multicolumn{2}{|c|}{ 95\% fiducial limit (ppm) } & \multirow[t]{2}{*}{ Chi-square } \\
\hline & & & & LCL & UCL & \\
\hline 12.5 & 8.00 & 97.30 & 493.50 & 60.89-217.06 & $219.20-5370.65$ & $9.775^{*}$ \\
\hline 25.0 & 16.60 & & & & & \\
\hline 50.0 & 21.80 & & & & & \\
\hline 100.0 & 44.60 & & & & & \\
\hline 200.0 & 79.40 & & & & & \\
\hline Control & 0.0 & & & & & \\
\hline
\end{tabular}

*Significant at $P<0.05$. P. perlata: Parmelia perlata, A. salina: Artemia salina, LCL: Lower confidence limit, UCL: Upper confidence limit, LC: Lethal concentration

Krishnaraj et al. (2005) found that the hydroalcoholic extract of the lichen showed an $\mathrm{LC}_{50} 730 \mathrm{ppm}$ which is comparatively very higher than the results obtained with all the extracts of P. perlata in this study.

The methanolic and ethanolic extract of P.perlata showed its effectiveness in inhibiting drug resistant Helicobacter pylori isolates (Gehlot et al., 2016). The results of methanol extract of Piper betle showed 100\% mortality of cysts only at 500 ppm with an $\mathrm{LC}_{50}$ value of $85.50 \mathrm{ppm}$ (Mae et al., 2014). These concentrations are much higher than our results. Sharma et al. (2014) identified dibenzofuran, 2-acetyl9b-carbmethoxy-7,9-dihydroxy-8-methyl-1,3(2H,9bH)dibenzofurandione, and 2,6-diacetyl-7,9-dihydroxy-8,9bdimethyl-1,3(2H,9bH)-dibenzofurandione also known as $(+)$ - usnic acid, as heterocyclic natural compounds from lichen P. perlata. The ethyl acetate, acetone, and methanol extract of $P$. perlata were found to possess inhibitory effect against Staphylococcus aureus (Vidyalakshmi and Kruthika, 2012).

Further investigations on P.perlata to find out the cytotoxic potential compound through a bioassay guided separation and also to find out the mechanism of action is suggested by this study.

\section{REFERENCES}

Desai AG, Qazi GN, Ganju RK, El-Tamer M, Singh J, Saxena AK, et al. Medicinal plants and cancer chemoprevention. Curr Drug Metab 2008;9:581-91.
Gehlot V, Mahant S, Vijayraghwan P, Das K, Hoda S, Das R. Therapeutic potential of lichen Parmelia perlata against dual drug-resistant Helicobacter pylori isolates. Int J Pharm Pharm Sci 2016;8:205-8.

Krishnaraj AV, Rao TV, Sundararaju D, Vanisree M, Tsay HS, Subbaraju GV.Assessment of bioactivity of Indian medicinal plants using brine shrimp (Artemia salina) lethality assay. Int J Appl Sci Eng 2005;3:125-34.

Mae ML, Socorro D, Bendoy CP, Dacayan CM. Cytotoxic effects of betel vine, Piper betle Linn. Leaf extracts using Artemia salina leach (brine shrimp lethality assay). J Multidiscip Stud 2014;3:100-11.

McRae J, Yang Q, Crawford R, Palombo E. Review of the methods used for isolating pharmaceutical lead compounds from traditional medicinal plants. Environmentalist 2007;27:165-74.

Otang WM, Grierson DS, Ndip RN. Assessment of potential toxicity of three South African medicinal plants using the brine shrimp (Artemia salina) assay. Afr J Pharm Pharmacol 2013;7:1272-9.

Priya ML, Priya KB, Kotakadi VS, Josthna P. Herbal and medicinal plants molecules towards treatment of cancer: A mini review. Am J Ethnomed 2015;2:136-42.

Rao JK, Suneetha J, Seetharami Reddi TV, Kumar OA. Ethnomedicine of the Gadabas, a primitive tribe of Visakhapatnam district, Andhra Pradesh. Int Multidiscip Res J 2011;1:10-4.

RichardTS, Kamdje AH, Mukhtar F. Medicinal plants in breast cancer therapy. J Dis Med Plants 2015;1:19-23.

Sabai KK, Thin NN, Shwe K, Htwe TM. Evaluation of the 
bioactivities of some Myanmar medicinal plants using brine shrimp (Artemia salina) toxicity test. J Myanmar Acad Techol 2001;1:105-12.

Sharma AK, Sharma KK, Sharma MC, Dobhal MP. Two dibenzofuran identified as heterocyclic natural compounds from lichen Parmelia perlata. J Pharmacogn Phytochem
2014;2:95-7.

Sharma N, Gupta PC, Singh A, Rao CV. Brine shrimp bioassay of Pentapetes phoenicea Linn. and Ipomoea carnea jacq. leaves. Der Pharm Lett 2013;5:162-7.

Vidyalakshmi A, Kruthika K. Antibacterial activity of Parmelia perlata. Asian Pac J Trop Biomed 2012;2:S892-4. 